Alaska Division of Geological \& Geophysical Surveys

Raw Data File 2016-7

\title{
ZIRCON U-Pb AGE DATA, RAY MOUNTAINS AREA, BETTLES QUADRANGLE, ALASKA
}

by

Amy L. Tuzzolino, Paul O'Sullivan, Lawrence K. Freeman, and Rainer J. Newberry

$\$ 3.00$

May 2016

THIS REPORT HAS NOT BEEN REVIEWED FOR TECHNICAL CONTENT

OR FOR CONFORMITY TO THE EDITORIAL STANDARDS OF DGGS

\author{
Released by \\ STATE OF ALASKA \\ DEPARTMENT OF NATURAL RESOURCES \\ Division of Geological \& Geophysical Surveys \\ 3354 College Road \\ Fairbanks, Alaska 99709-3707
}





\section{TABLE OF CONTENTS}

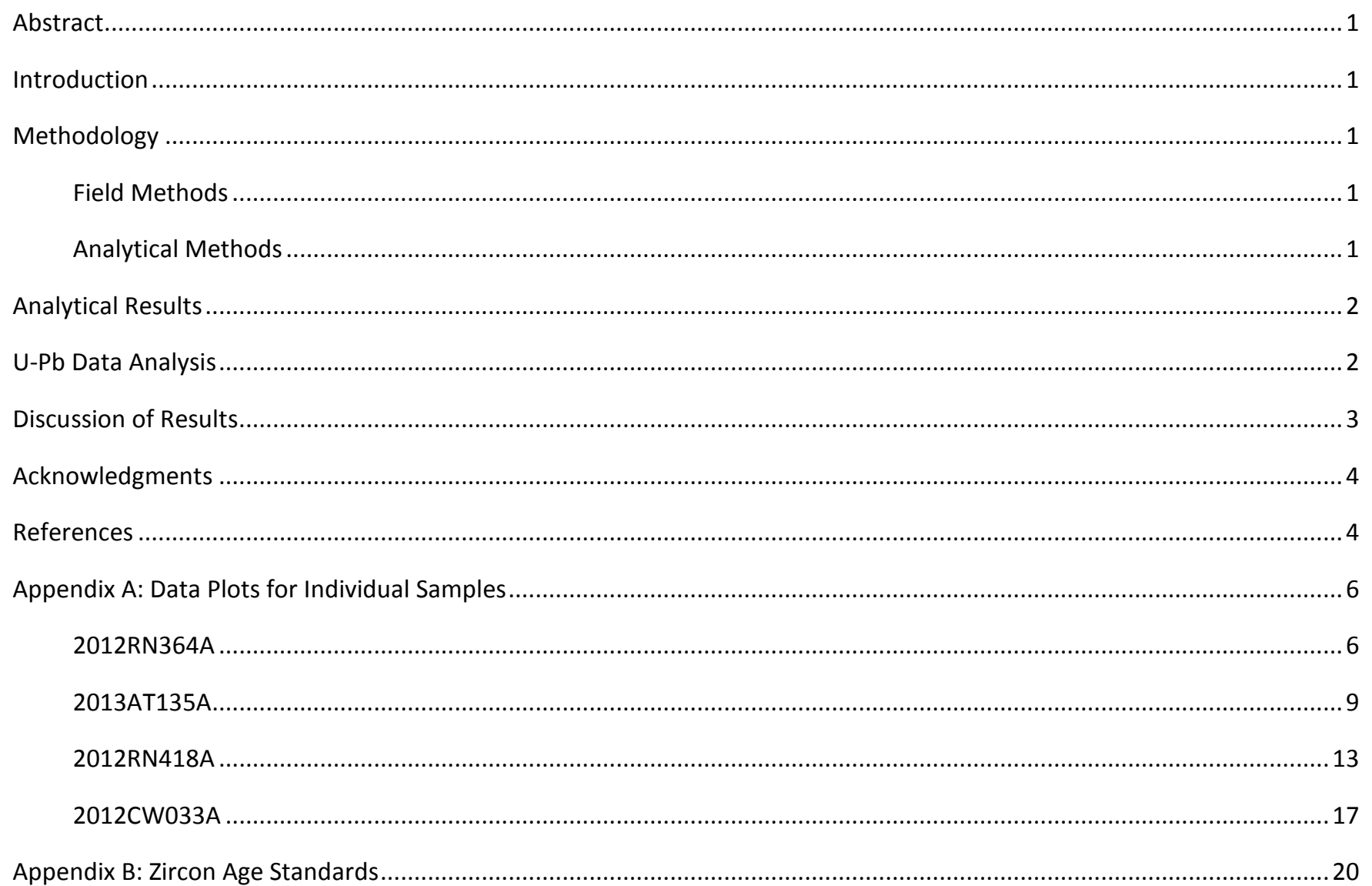

\section{LIST OF TABLES}

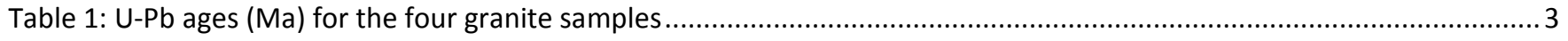





\section{Zircon U-Pb age data, Ray Mountains area, Bettles Quadrangle, Alaska}

by

Amy L. Tuzzolino ${ }^{1}$, Paul B. O'Sullivan², Lawrence K. Freeman³ ${ }^{3}$ and Rainer J. Newberry ${ }^{1}$

\section{SUMMARY}

$\mathrm{U}-\mathrm{Pb}$ analyses were performed on igneous rocks from the Ray Mountains area of west-central Alaska. The plutonic samples have ages ranging from $98.0 \pm 0.9 \mathrm{Ma}$ to $111.6 \pm 1.0 \mathrm{Ma}$.

\section{INTRODUCTION}

In 2012, the State of Alaska established its Strategic and Critical Minerals (SCM) Assessment project, a Statefunded Capital Improvement Project (CIP), to evaluate Alaska's statewide potential for SCM resources. The project is being implemented by the Alaska Division of Geological \& Geophysical Surveys (DGGS), and involves obtaining new airborne-geophysical, geological, and geochemical data.

DGGS conducted a multi-year project, from 2012 through 2013, to study the geology and economic potential of rare-earth elements (REE) and other metals in the Ray Mountains in the Beaver, Bettles, Livengood, and Tanana quadrangles (Bachmann and others, 2013; Tuzzolino and others, 2014a). To better understand the granitic rocks that are associated with REE and tin-polymetallic occurrences in the area, four samples were collected for $\mathrm{U}-\mathrm{Pb}$ geochronologic analyses. These new age analyses will allow us to better evaluate the geochronology of the granitic rocks that are the apparent source of the alluvial REE and tin resources.

The purpose of this DGGS Raw Data File is to present the U-Pb age results of the Ray Mountains study. Analyses were performed by the Apatite to Zircon, Inc. (A2Z) laboratory. Additional ${ }^{40} \mathrm{Ar} /{ }^{39} \mathrm{Ar}$ ages for the Ruby batholith were published in a separate release (Tuzzolino and others, 2014b).

The sample location coordinates and analytical data tables associated with this report are available in digital format as comma-separated value (CSV) files. Additional details about the organization of information are noted in the accompanying metadata file. All files can be downloaded from the DGGS website (doi:10.14509/29662).

\section{METHODOLOGY}

\section{Field Methods}

DGGS field geologists collected rock samples from the surface or within $0.5 \mathrm{~m}$ of the surface. Care was taken to collect fresh, unweathered rock samples representative of igneous rock types in the map area. Locations were recorded using handheld, WAAS-enabled GPS devices. WAAS-enabled GPS devices have a reported error of about $1 \mathrm{~m}$ (NSTB/WAAS T\&E Team, 2006). Depending on degradation of the WAAS and GPS signals, the horizontal position error of sample locations in this report is in the range of 1-10 $\mathrm{m}$. The originating coordinate system for samples collected in 2012 (2012CW033A, 2012RN364A and 2012RN418A) was NAD27, UTM zone 5. Sample 2013AT135A was collected using WGS1984 Web Mercator Auxiliary Sphere coordinate system as specified by the settings of the collectors used. To provide a consistent coordinate system for all samples, all location coordinates of the samples collected in 2012 were transformed to WGS1984 Web Mercator Auxiliary Sphere using NAD_1927_To_NAD_1983_Alaska+WGS_1984_(ITRF00)_To_NAD_1983 transformation. Latitude and longitude

\footnotetext{
${ }_{1}^{1}$ University of Alaska Fairbanks Department of Geology \& Geophysics, P.O. Box 755780, Fairbanks, Alaska 99775-5780

2 Apatite to Zircon, Inc., 1075 Matson Road, Viola, Indiana 83872-9709

${ }^{3}$ Alaska Division of Geological \& Geophysical Surveys, 3354 College Road, Fairbanks, Alaska 99709-3707; larry.freeman@alaska.gov
} 
coordinates of the samples are provided in the accompanying .csv file. This file also contains brief descriptions of each sample based on field observations.

\section{Analytical Methods}

DGGS submitted selected rock samples to A2Z in 2014. Paul O'Sullivan directed the processing and analyses of the samples in the A2Z laboratory in Viola, Idaho, where laser-ablation-inductively coupled plasma-mass spectrometry (LA-ICP-MS) analyses were performed on an Agilent 7700x quadrapole mass spectrometer attached to a Resonetics RESOlution M50 Excimer laser. Detailed discussion of the laboratory techniques is provided in Donelick and others (2005) and Solie and others (2014).

\section{ANALYTICAL RESULTS}

Four plutonic rocks, consisting of monzogranites and a syenogranite, were analyzed. The mean error-weighted ${ }^{206} \mathrm{~Pb} /{ }^{238} \mathrm{U}$ and mean $\mathrm{U}-\mathrm{Pb}$ concordia-calculated ages (Ma) from zircons in each sample are recorded in the accompanying .csv table. All four ages fall within a span of about 14 million years, between 98.0 Ma (2012RN364A) and 111.8 Ma (2012CW033A). U-Pb concordia diagrams, histograms, and mean error-weighted probability plots for each sample are provided in Appendix A, from youngest to oldest.

\section{U-PB DATA ANALYSIS}

The raw data received from $A 2 Z$ were reviewed and processed at DGGS. First, the failed and peak-backgroundcorrected ( $\mathrm{pbc}$ ) analyses were excluded from the age calculations. These initial criteria are noted in the accompanying data tables for individual samples. Next, the analyses for each sample were plotted on concordia plots using Isoplot v. 3.7 (Ludwig, 2008). In two cases, samples 2013AT135A and 2012RN418A, the datasets yielded poorly defined chords, with mid-Cretaceous lower intercepts and early Paleozoic to late Proterozoic upper intercepts. The data quality are not sufficient to use the ages so defined, but they do indicate a small amount of contamination from older, inherited zircon.

To further reduce the data, the relative ${ }^{206} \mathrm{~Pb} /{ }^{238} \mathrm{U}$ age error was calculated using the ${ }^{206} \mathrm{~Pb} /{ }^{238} \mathrm{U}$ age and the

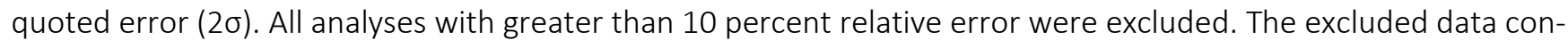
sistently included those samples with anomalously old ages.

Histograms of ${ }^{206} \mathrm{~Pb} /{ }^{238} \mathrm{U}$ ages were constructed to identify age populations well outside of the means. For sample 2012RN418A, a single, anomalously old age was excluded. The mean error-weighted ages for the remaining ${ }^{206} \mathrm{~Pb} /{ }^{238} \mathrm{U}$ ages were calculated (table 1 ).

Next, the percent deviation from the concordia was calculated. The equation that was used calculates the extent that the measured ${ }^{207} \mathrm{~Pb} /{ }^{235} \mathrm{U}$ deviates from the concordia, assuming the measured ${ }^{206} \mathrm{~Pb} /{ }^{238} \mathrm{U}$ ratio lies on the concordia. In several cases, data that plots increasingly farther from the concordia gives increasingly older ages, again indicating a physical mixing of $\mathrm{Pb}$ and $\mathrm{U}$ from early Paleozoic to late Proterozoic and from Cretaceous zircon.

Following the elimination of data deviating more than 2-3 percent from the concordia, a mean concordia age (table 1) was calculated using Isoplot software (Ludwig, 2008). In general, the mean ${ }^{206} \mathrm{~Pb} /{ }^{238} \mathrm{U}$ age and the mean concordia age are indistinguishable, within error, with a smaller error for the concordia age. The authors prefer the resulting mean concordia age, as generally having smaller error and fewer inherited components. 
Table 1: U-Pb ages (Ma) for the four granite samples.

\begin{tabular}{|c|c|c|c|c|c|c|}
\hline Sample & $\begin{array}{c}\text { Lab Sample } \\
\text { Number }\end{array}$ & Latitude & Longitude & Pluton & $\begin{array}{c}\text { Mean Error-Weighted } \\
206 \mathrm{~Pb} /{ }^{238} \mathrm{U} \text { Age } \pm 2 \sigma\end{array}$ & $\begin{array}{c}\text { Mean Concordia } \\
\text { Age } \pm 2 \sigma\end{array}$ \\
\hline 2012RN364A & 12RN364A & 66.35686 & -150.4650 & Hot Springs & $98.6 \pm 1.0 \mathrm{Ma}$ & $98.0 \pm 0.9 \mathrm{Ma}$ \\
\hline 2013AT135A & 13AT135A & 66.10740 & -150.0470 & No Name Creek & $107.0 \pm 1.2 \mathrm{Ma}$ & $106.6 \pm 1.3 \mathrm{Ma}$ \\
\hline 2012RN418A & 12RN418A & 66.05439 & -150.5030 & Ray River & $111.0 \pm 1.3 \mathrm{Ma}$ & $110.6 \pm 1.1 \mathrm{Ma}$ \\
\hline 2012CW033A & 12CW033A & 66.51191 & -150.2000 & Kanuti & $111.7 \pm 1.0 \mathrm{Ma}$ & $111.6 \pm 1.0 \mathrm{Ma}$ \\
\hline
\end{tabular}

\section{DISCUSSION OF RESULTS}

The samples are presented in chronological order, from youngest apparent age to oldest.

2012RN364A-Zircon from the interior of the Hot Springs pluton: 60 analyses were attempted; 50 analyses were used to calculate a mean error-weighted ${ }^{206} \mathrm{~Pb} /{ }^{238} \mathrm{U}$ age of $98.6 \pm 1.0 \mathrm{Ma}$. Seventeen analyses were used to calculate a mean concordia age of $98.0 \pm 0.9 \mathrm{Ma}$.

2013AT135A-Zircon from the southern boundary of the No Name Creek pluton: 60 analyses were attempted; 49 analyses were used to calculate a mean error-weighted ${ }^{206} \mathrm{~Pb} /{ }^{238} \mathrm{U}$ age of $107.0 \pm 1.2 \mathrm{Ma}$. Eighteen analyses were used to calculate a mean concordia age of $106.6 \pm 1.3 \mathrm{Ma}$.

2012RN418A-Zircon from the western portion of the Ray River pluton: 60 analyses were attempted; 46 analyses were used to calculate a mean error-weighted ${ }^{206} \mathrm{~Pb} /{ }^{238} \mathrm{U}$ age of $111.0 \pm 1.3 \mathrm{Ma}$. Twenty-one analyses were used to calculate a mean concordia age of $110.6 \pm 1.1 \mathrm{Ma}$.

2012CW033A-Zircon from the interior of the Kanuti pluton: 60 analyses were attempted; 55 analyses were used to calculate a mean error-weighted ${ }^{206} \mathrm{~Pb} /{ }^{238} \mathrm{U}$ age of $111.7 \pm 1.0 \mathrm{Ma}$. Twenty-six analyses were used to calculate a mean concordia age of $111.6 \pm 1.0 \mathrm{Ma}$.

$\mathrm{U}-\mathrm{Pb}$ analyses of zircons ideally yield the same ${ }^{206} \mathrm{~Pb} /{ }^{238} \mathrm{U}$ and ${ }^{207} \mathrm{~Pb} /{ }^{235} \mathrm{U}$ ages, indicating concordance. Lack of concordance indicates partially inherited thermal disturbance. Because the samples are not entirely concordant (figs. 1b, 2b, 3b, 4b), we prefer to take a subset of ages approximately concordant and use the average of these ages - the mean concordia age ( $\mathrm{Ma}$ ). The smaller sample size used to calculate the mean concordia age minimizes the effects of inherited zircons, and thus yields slightly smaller uncertainties.

\section{ACKNOWLEDGMENTS}

This project was funded by the Alaska State Legislature through the Strategic and Critical Minerals Assessment project, a constituent of the Alaska Airborne Geophysical/Geological Mineral Inventory program. Samples in this report were collected by Rainer Newberry, Amy Tuzzolino, and Colby Wright of the University of Alaska Fairbanks. Margaret Donelick (A2Z) provided technical assistance with sample preparation; Paul O'Sullivan and Ray Donelick (A2Z), as well as Rainer Newberry and Alicja Wypych (DGGS), provided assistance with LA-ICP-MS data interpretation.

\section{REFERENCES}

Bachmann, E.N., Blessington, M.J., Freeman, L.K., Newberry, R.J., Tuzzolino, A.L., Wright, T.C., and Wylie, William, 2013, Geochemical major-oxide, minor-oxide, trace-element, and rare-earth-element data from rocks and stream sediments collected in 2012 in the Ray Mountains area, Beaver, Bettles, Livengood, and Tanana quadrangles, Alaska: Alaska Division of Geological \& Geophysical Surveys Raw Data File 2013-5, 4 p. doi: $\underline{10.14509 / 25386}$

Barker, J.C., and Foley, J.Y., 1986, Tin reconnaissance of the Kanuti and Hodzana rivers uplands, central Alaska: U.S. Bureau of Mines IC 9104, 27 p. http://dggs.alaska.gov/pubs/id/21287 
Black, L.P., and Gulson, B.L., 1978, The age of the Mud Tank Carbonatite, Strangways Range, Northern Territory: BMR Journal of Australian Geology \& Geophysics, v. 3, no. 3, p. 227-232.

Black, L.P., Kamo, S.L., Allen, C.M., Davis, D.W., Aleinikoff, J.N., Valley, J.W., Mundil, Roland, Campbell, I.H., Korsch, R.J., Williams, I.S., and Foudoulis, Chris, 2004, Improved ${ }^{206} \mathrm{~Pb} /{ }^{238} \mathrm{U}$ microprobe geochronology by the monitoring of trace-element-related matrix effect; SHRIMP, ID-TIMS, ELA-ICP-MS and oxygen isotope documentation for a series of zircon standards: Chemical Geology, v. 205, no. 1-2, p. 115-140. doi:10.1016/j.chemgeo.2004.01.003

Black, L.P., Kamo, S.L., Allen, C.M., Aleinikoff, J.N., Davis, D.W., Korsch, R.J., and Foudoulis, Chris, 2003, TEMORA 1: A new zircon standard for Phanerozoic U-Pb geochronology: Chemical Geology, v. 200, no. 1-2, p. 155-170. doi:10.1016/S0009-2541(03)00165-7

Donelick, R.A, O'Sullivan, P.B., and Ketcham, R.A., 2005, Apatite fission-track analysis: Reviews in Mineralogy and Geochemistry, Mineralogical Society of America, v. 58, no. 1, p. 49-94. doi:10.2138/rmg.2005.58.3

Kuiper, K.F., Deino, A., Hilgen, P.J., Krijgsman, W., Renne, P.R., and Wijbrans, J.R., 2008, Synchronizing rock clocks of Earth history: Science, v. 320, no. 5875, p. 500-504. doi:10.1126/science.1154339

Lanphere, M.A., and Baadsraard, H., 2001, Precise K-Ar, ${ }^{40} \mathrm{Ar} /{ }^{39} \mathrm{Ar}$, Rb-Sr and U-Pb mineral ages from the $27.5 \mathrm{Ma}$ Fish Canyon Tuff reference standard: Chemical Geology, v. 175, no. 3-4, p. 653-671. doi:10.1016/S00092541(00)00291-6

Ludwig, K.R., 2008, User's manual for Isoplot version 3.7, A geochronological toolkit for Microsoft Excel: Berkeley Geochronology Center, Special Publication 4, 76 p.

Miller, T.P., 1989, Contrasting plutonic rock suites of the Yukon-Koyukuk basin and the Ruby geanticline, Alaska: Journal of Geophysical Research, v. 94, no. B11, p. 15,969-15,987.

NSTB/WAAS T\&E Team, 2006, Wide-area augmentation system performance analysis report, reporting period April 1 to June 30, 2006: Federal Aviation Administration (FAA)/William J. Hughes Technical Center, NSTB/WAAS T\&E Team, Atlantic City International Airport. http://www.nstb.tc.faa.gov/

Paces, J.B., and Miller, J.D., Jr., 1993, Precise U-Pb ages of Duluth Complex and related mafic intrusions, northeastern Minnesota-Geochronological insights to physical, petrogenetic, paleomagnetic, and tectonomagnetic processes associated with the $1.1 \mathrm{Ga}$ Midcontinent Rift System: Journal of Geophysical Research, v. 98, no. B8, p. 13,997-14,013. doi:10.1029/93JB01159

Renne, P.R., Swisher, C.C., Deino, A.L., Karner, D.B., Owens, T.L., and DePaolo, D.J., 1998, Intercalibration of standards, absolute ages and uncertainties in ${ }^{40} \mathrm{Ar} /{ }^{39} \mathrm{Ar}$ dating: Chemical Geology, v. 145, no. 1-2, p. 117-152. doi:10.1016/S0009-2541(97)00159-9

Solie, D.N., O’Sullivan, P.B., Werdon, M.B., Freeman, L.K., Newberry, R.J., Szumigala, D.J., and Hubbard, T.D., 2014, Zircon U-Pb age data, Alaska Highway Corridor, Tanacross and Nabesna quadrangles, Alaska: Alaska Division of Geological \& Geophysical Surveys Raw Data File 2014-16, 29 p. doi: 10.14509/27322

Tuzzolino, A.L., Freeman, L.K., and Newberry, R.J., 2014a, Geochemical major-oxide, minor-oxide, trace-element, and rare-earth-element data from rock samples collected in 2013 in the Ray Mountains area, Bettles A-1 and A-6 quadrangles, Alaska: Alaska Division of Geological \& Geophysical Surveys Raw Data File 2014-17, 3 p. doi:10.14509/27325

Tuzzolino, A.L., Newberry, R.J., Benowitz, J.A., Layer, P.W., and Freeman, L.K., 2014b, ${ }^{40} \mathrm{Ar} /{ }^{39} \mathrm{Ar}$ data, Ray Mountains area, Bettles Quadrangle, Alaska: Alaska Division of Geological \& Geophysical Surveys Raw Data File 2014-19, 12 p. doi:10.14509/29124 
APPENDIX A: DATA PLOTS FOR INDIVIDUAL SAMPLES

2012RN364A

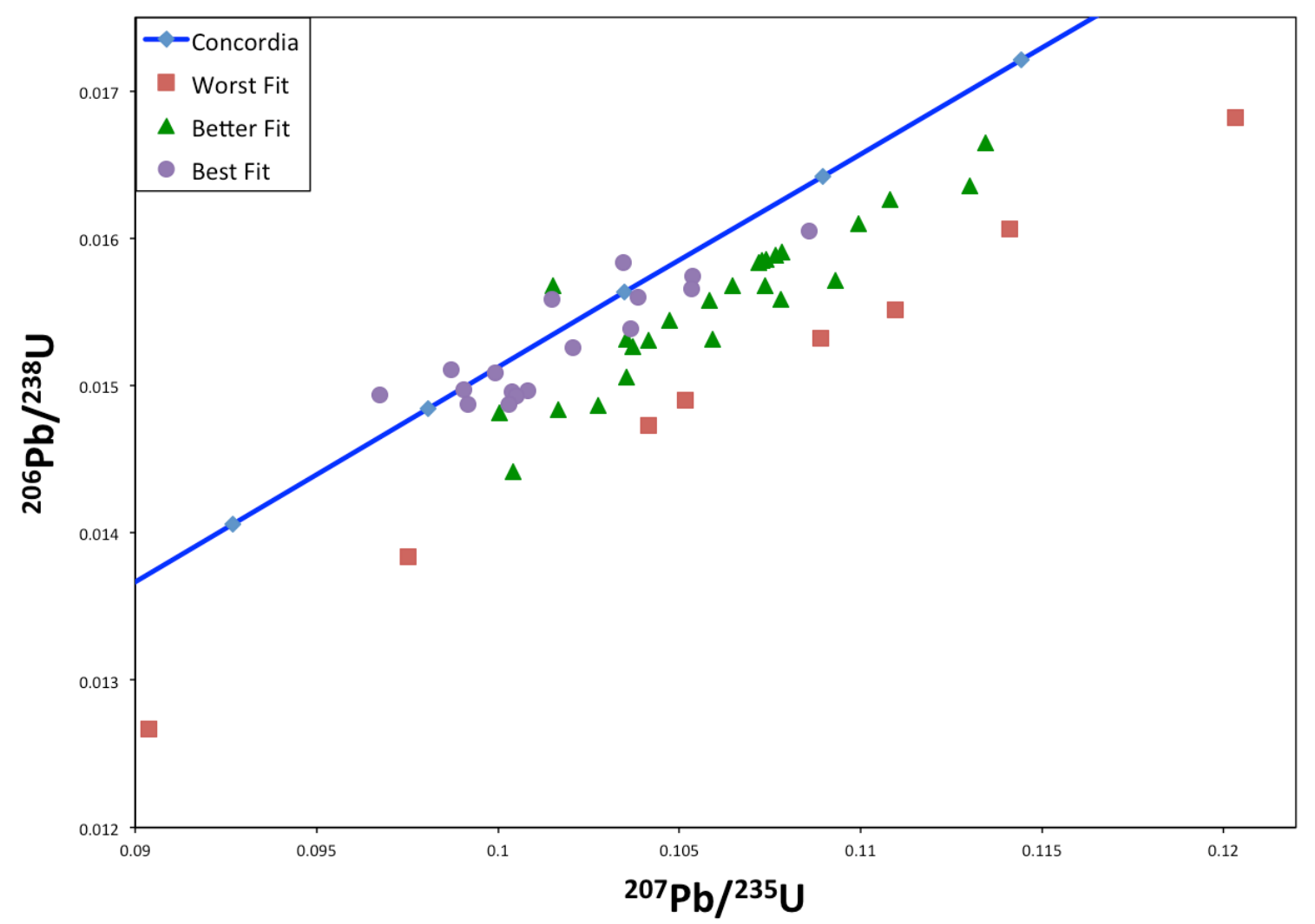

Figure 1a. 50 sets of analyses with relative error $<10$ percent, plotted to express relation to concordia. 


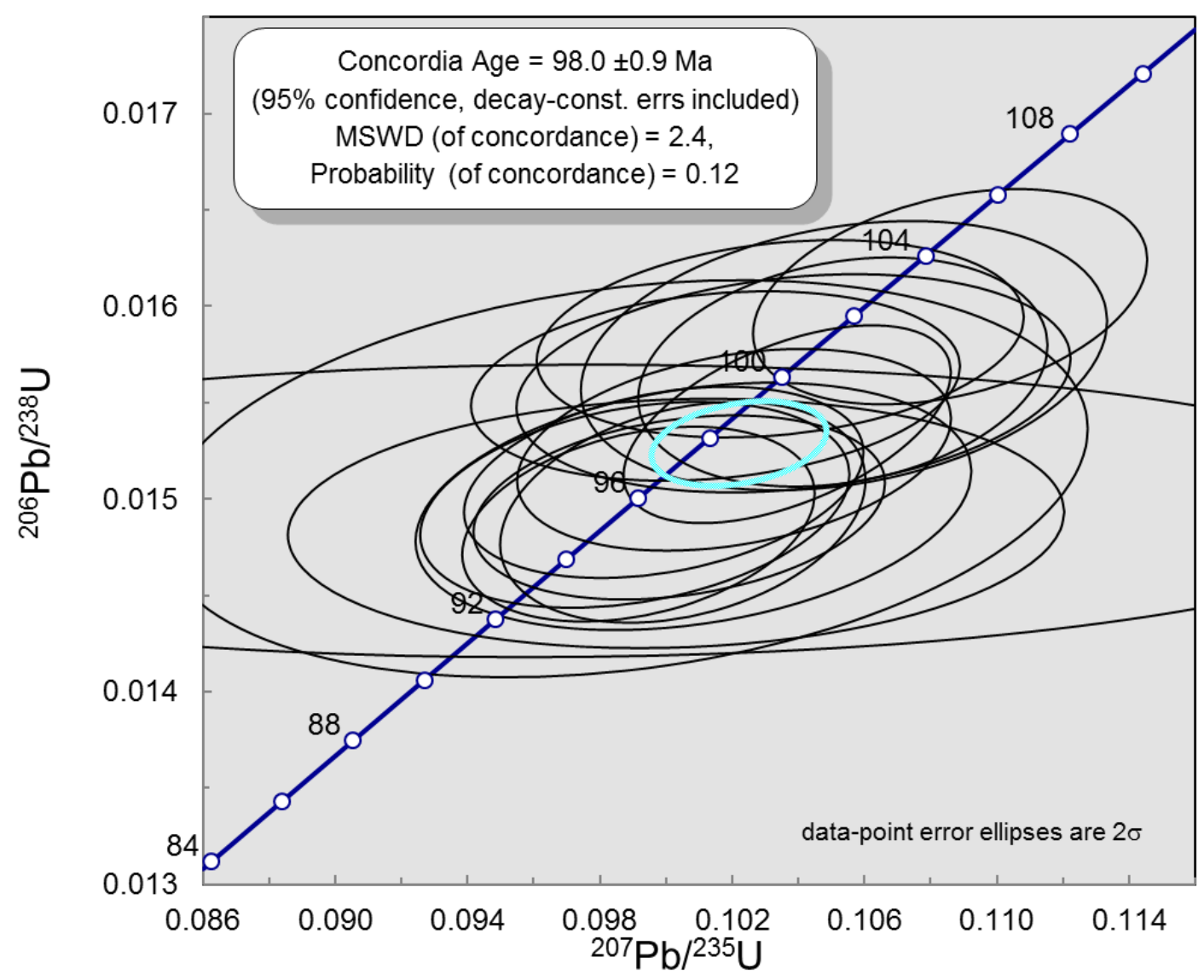

Figure $1 \mathrm{~b}$. U-Pb concordia-calculated age based upon 17 analyses, with ${ }^{207} \mathrm{~Pb} /{ }^{235} \mathrm{U}$ deviating from the concordia by $<2$ percent.

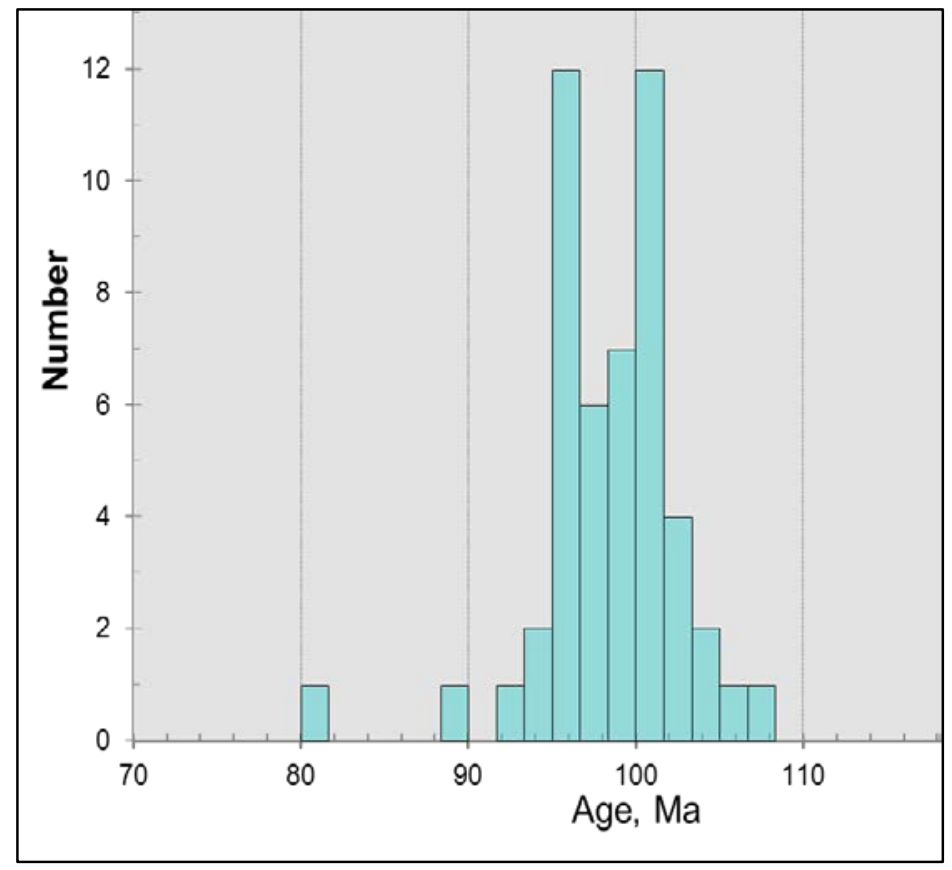

Figure 1c. 50 age measurements with relative error $<10$ percent. 


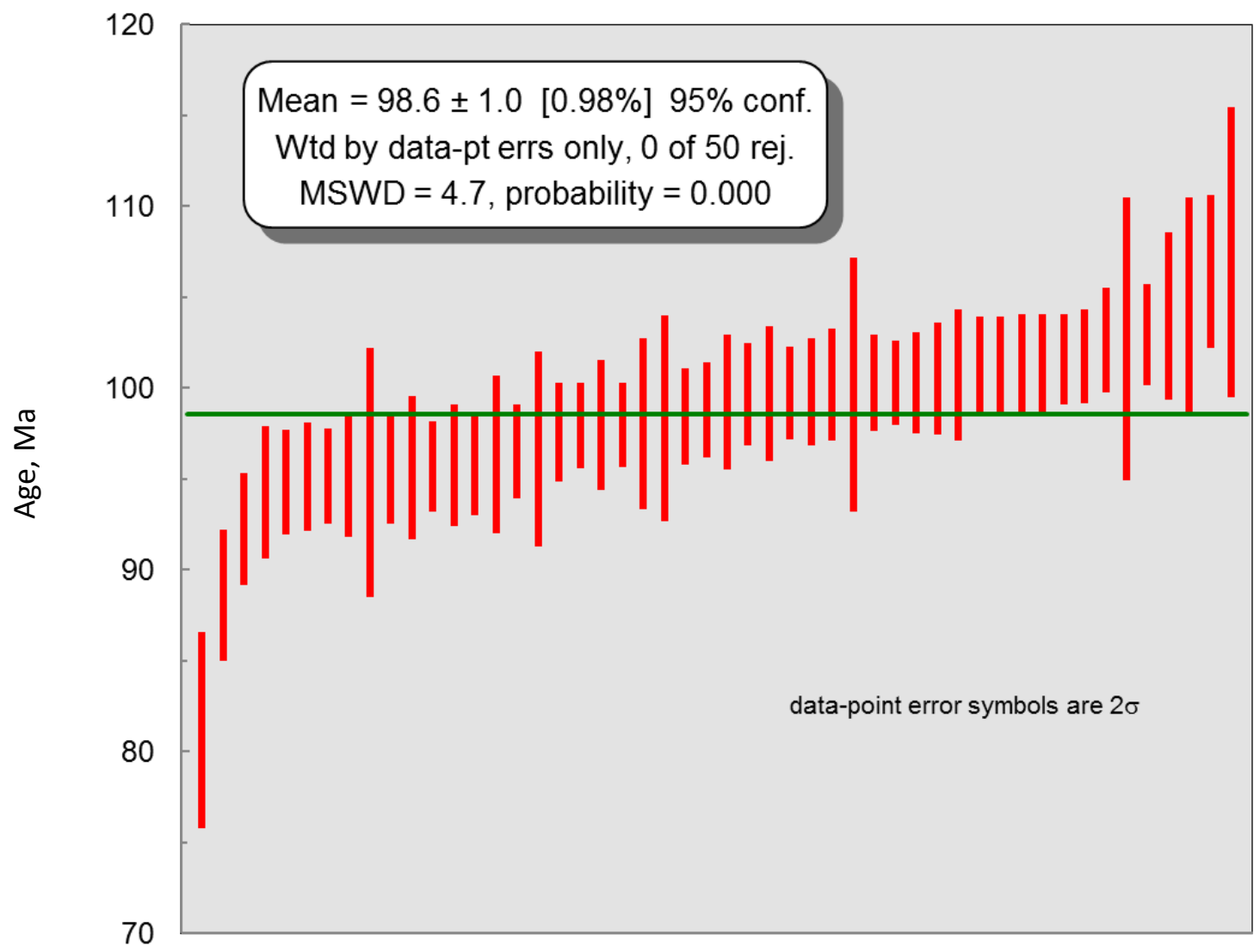

Figure $1 \mathrm{~d}$. Mean error-weighted ${ }^{206} \mathrm{~Pb} /{ }^{238} \mathrm{U}$ ages for 50 analyses, all with $<10$ percent relative error. 


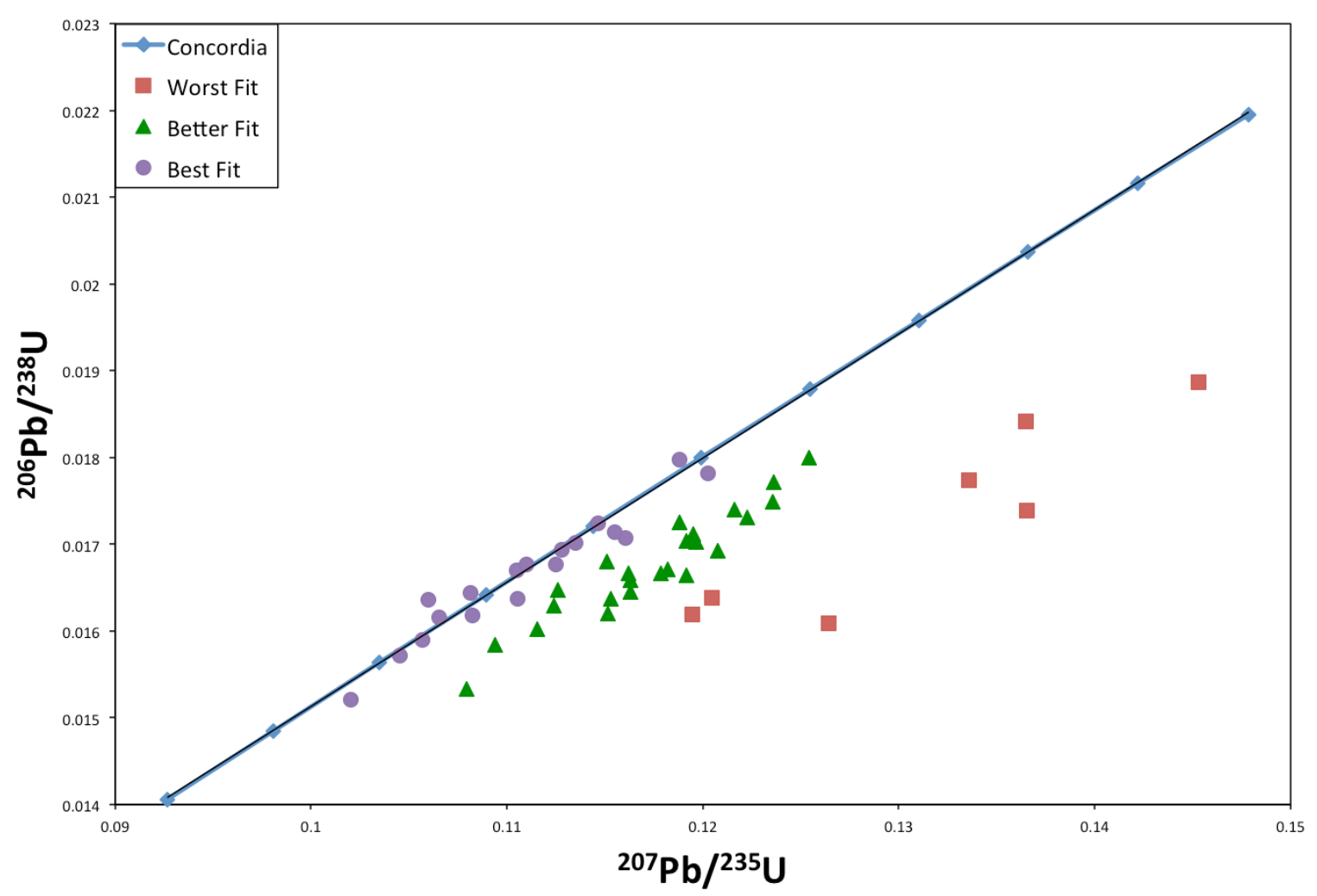

Figure 2 a. 49 sets of analyses with relative error $<10$ percent, plotted to express relation to concordia. 


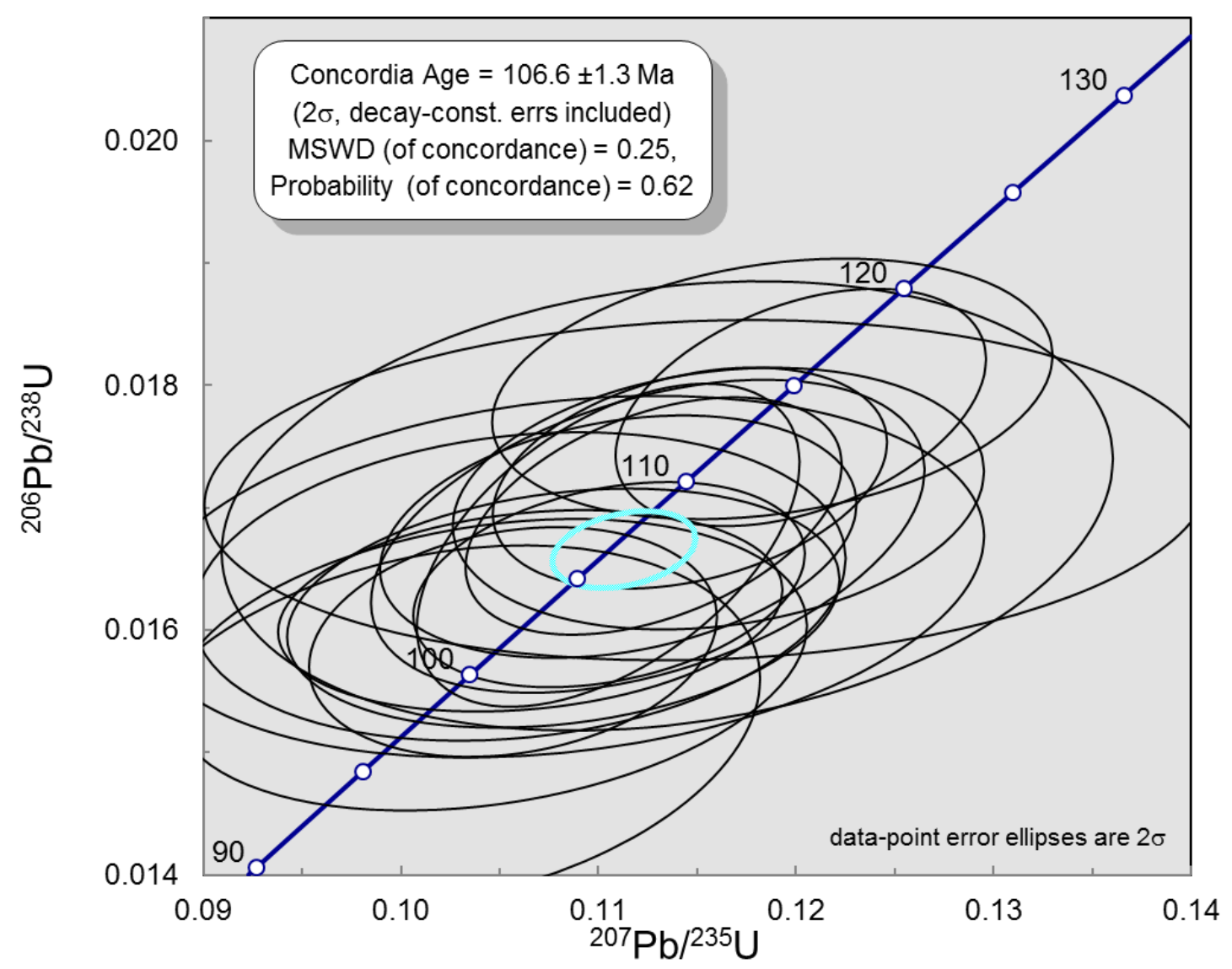

Figure $2 \mathrm{~b}$. U-Pb concordia-calculated age based upon 18 analyses, with ${ }^{207} \mathrm{~Pb} /{ }^{235} \mathrm{U}$ deviating from the concordia by $<2$ percent.

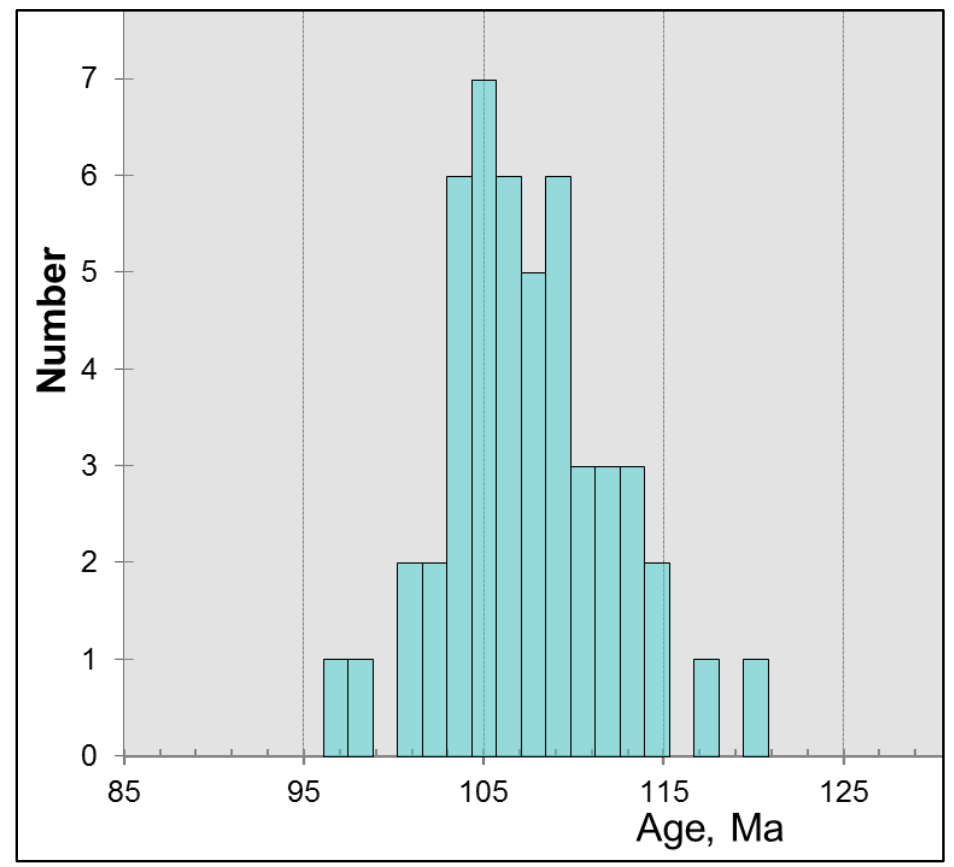




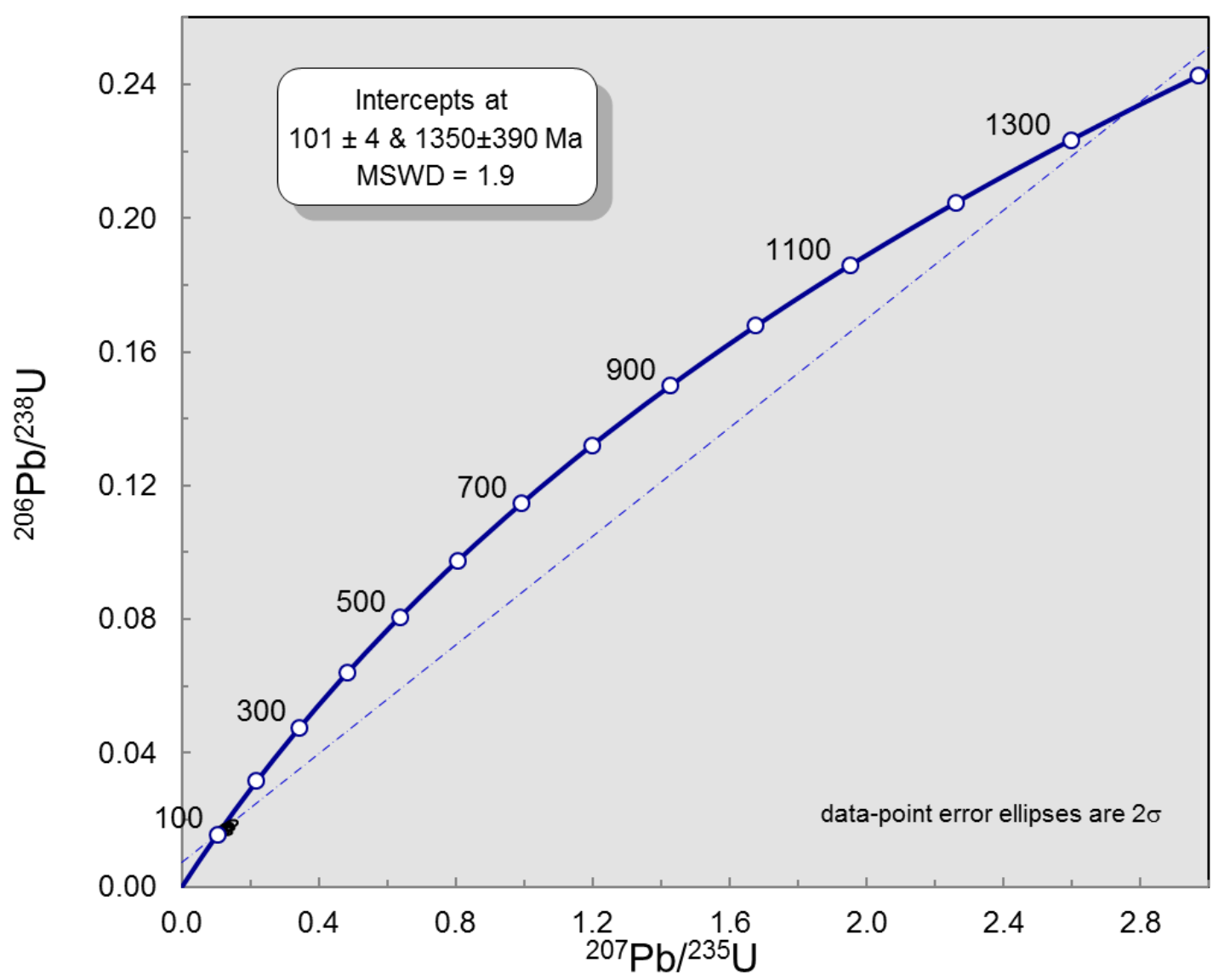

Figure $2 \mathrm{~d}$. All 55 measurements (including those with relative error $>10$ percent) define a two-point isochron with a Proterozoic upper-age intercept and a Middle Cretaceous lower-age intercept, indicating physical contamination of magmatic zircon with older, inherited zircon. 


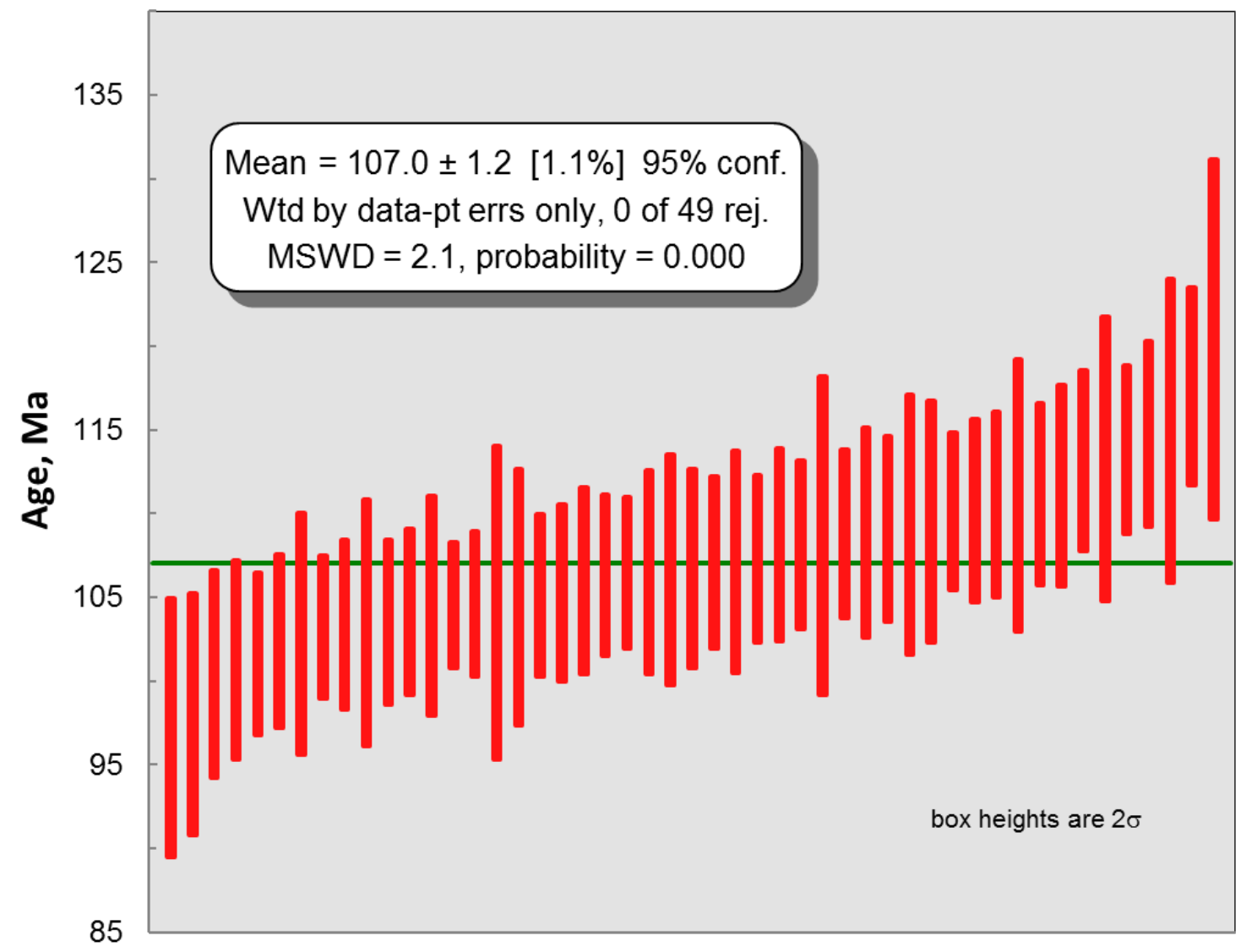

Figure 2e. Mean error-weighted ${ }^{206} \mathrm{~Pb} /{ }^{238} \mathrm{U}$ ages for 49 analyses, all with $<10$ percent relative error. 


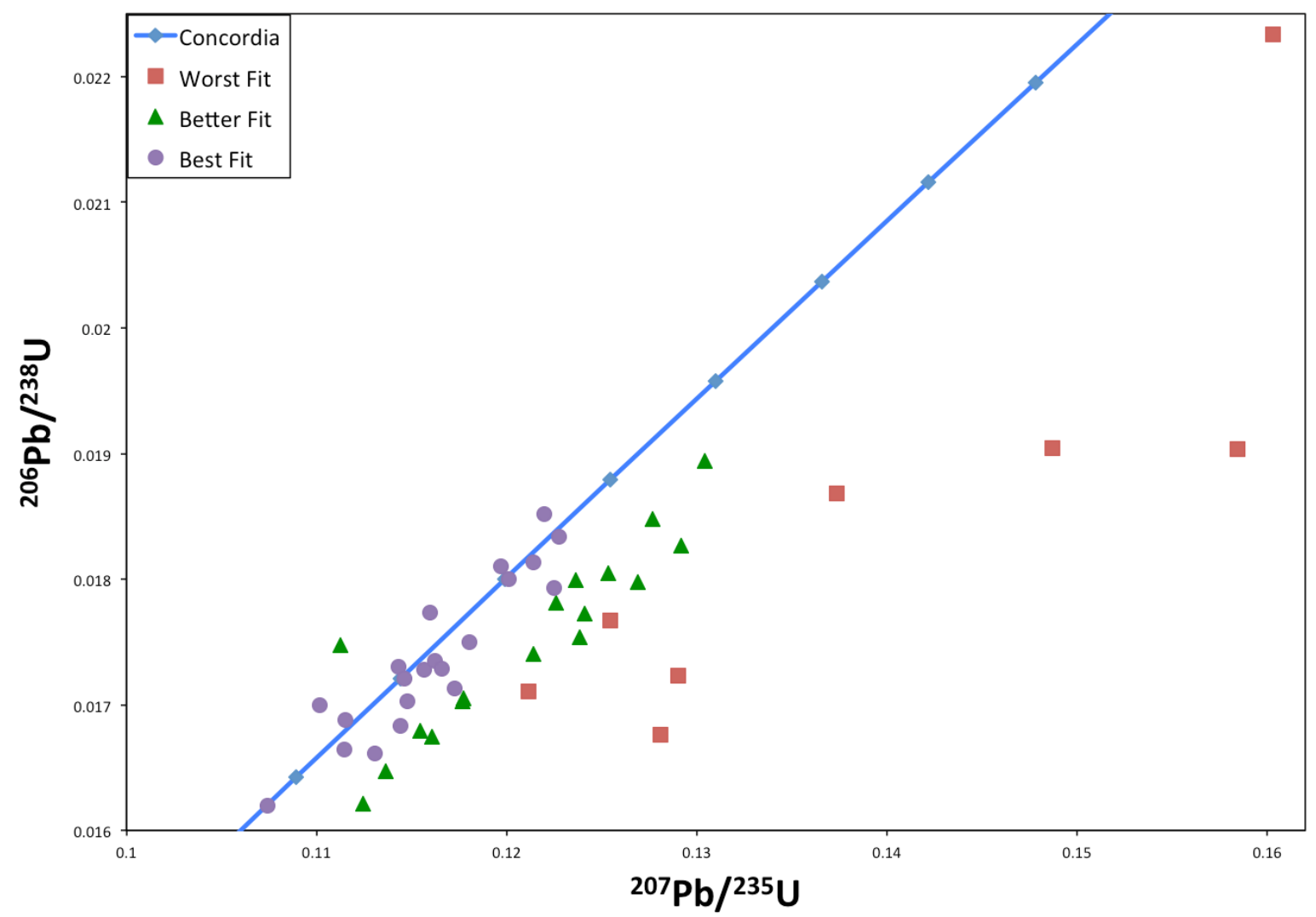

Figure 3a. 46 sets of analyses with relative error $<10$ percent, plotted to express relation to concordia. 


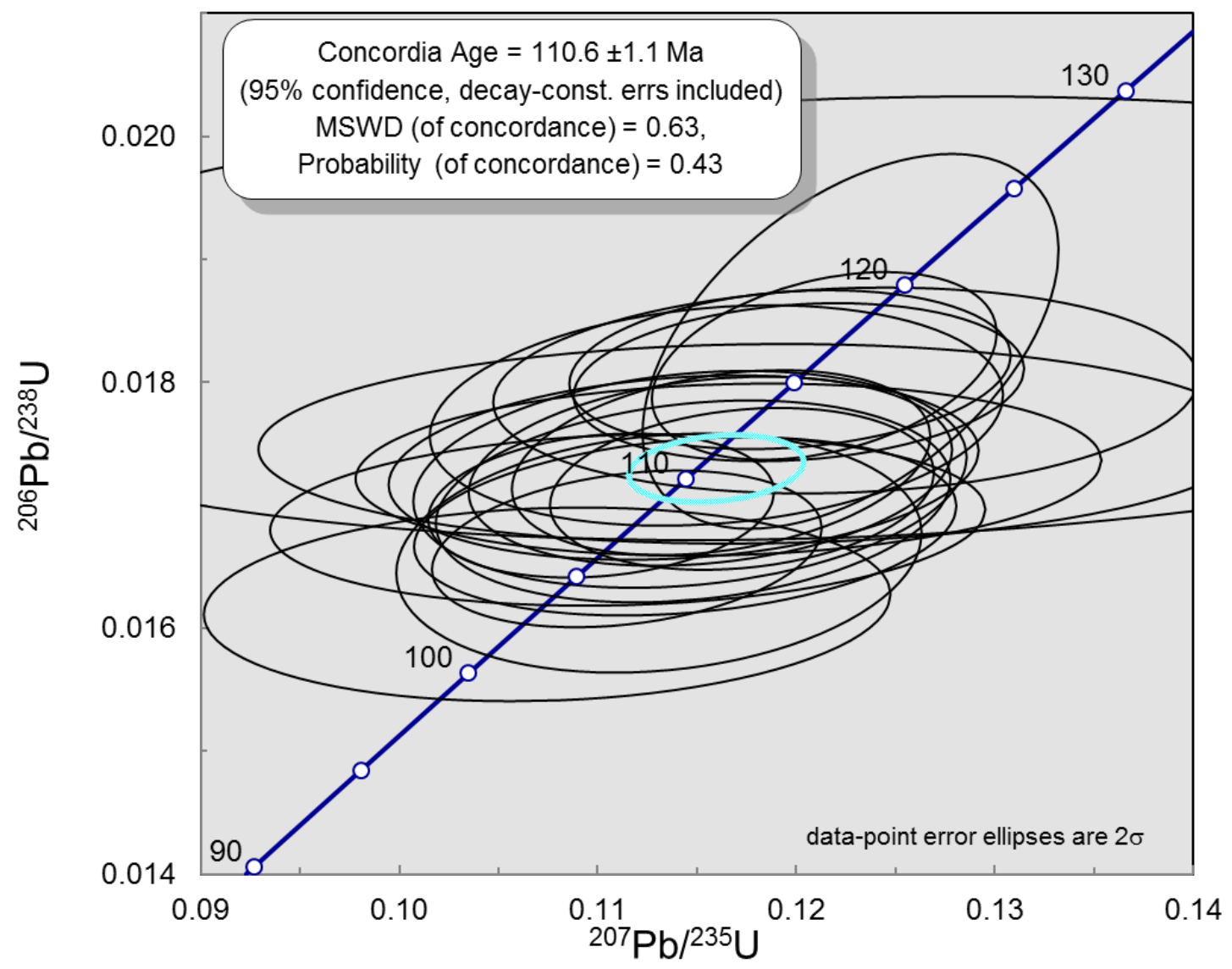

Figure $3 b$. U-Pb concordia-calculated age based on 21 analyses, with ${ }^{207} \mathrm{~Pb} /{ }^{235} \mathrm{U}$ deviating from the concordia by $<3$ percent.

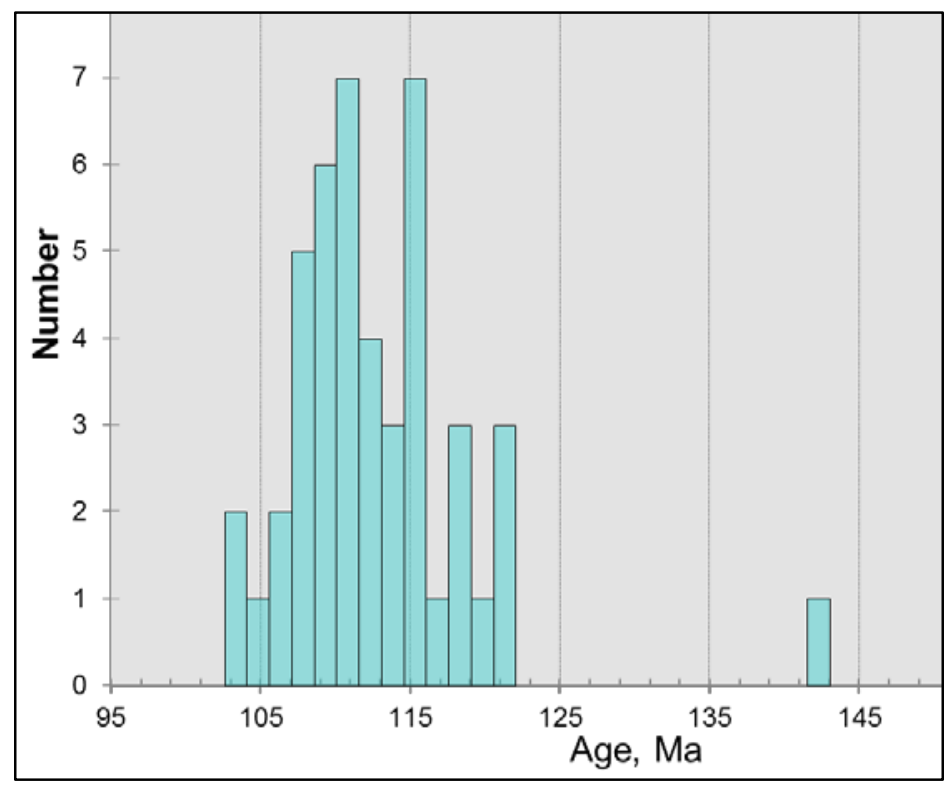

Figure 3c. 46 age measurements with relative error $<10$ percent. Note the outlier $144 \mathrm{Ma}$, which is not part of the main population. 


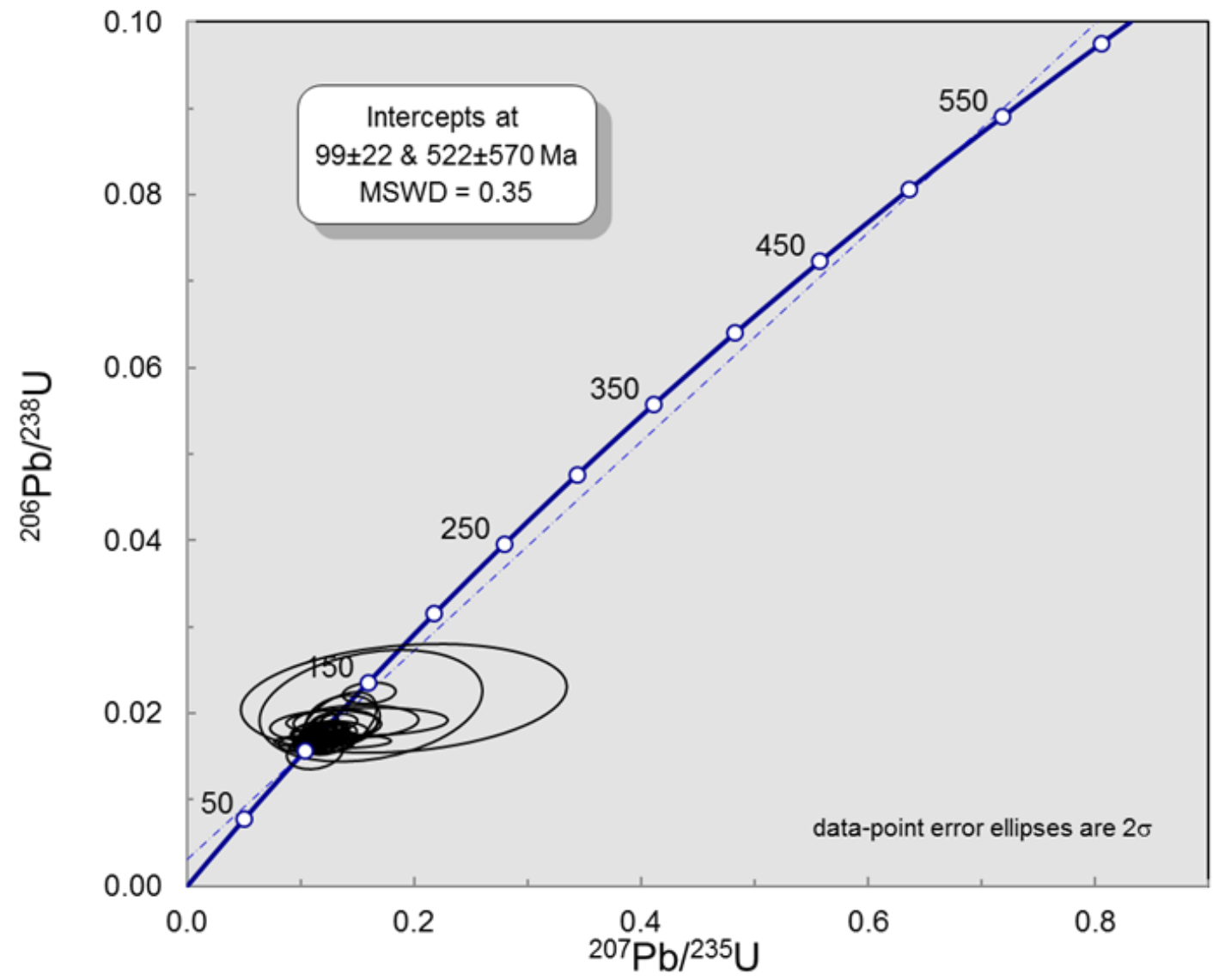

Figure 3d. All 52 measurements (including those with relative error $>10$ percent) poorly define a two-point isochron with an Early Paleozoic upper-age intercept and a Middle Cretaceous lower-age intercept, indicating physical contamination of magmatic zircon with older, inherited zircon. 


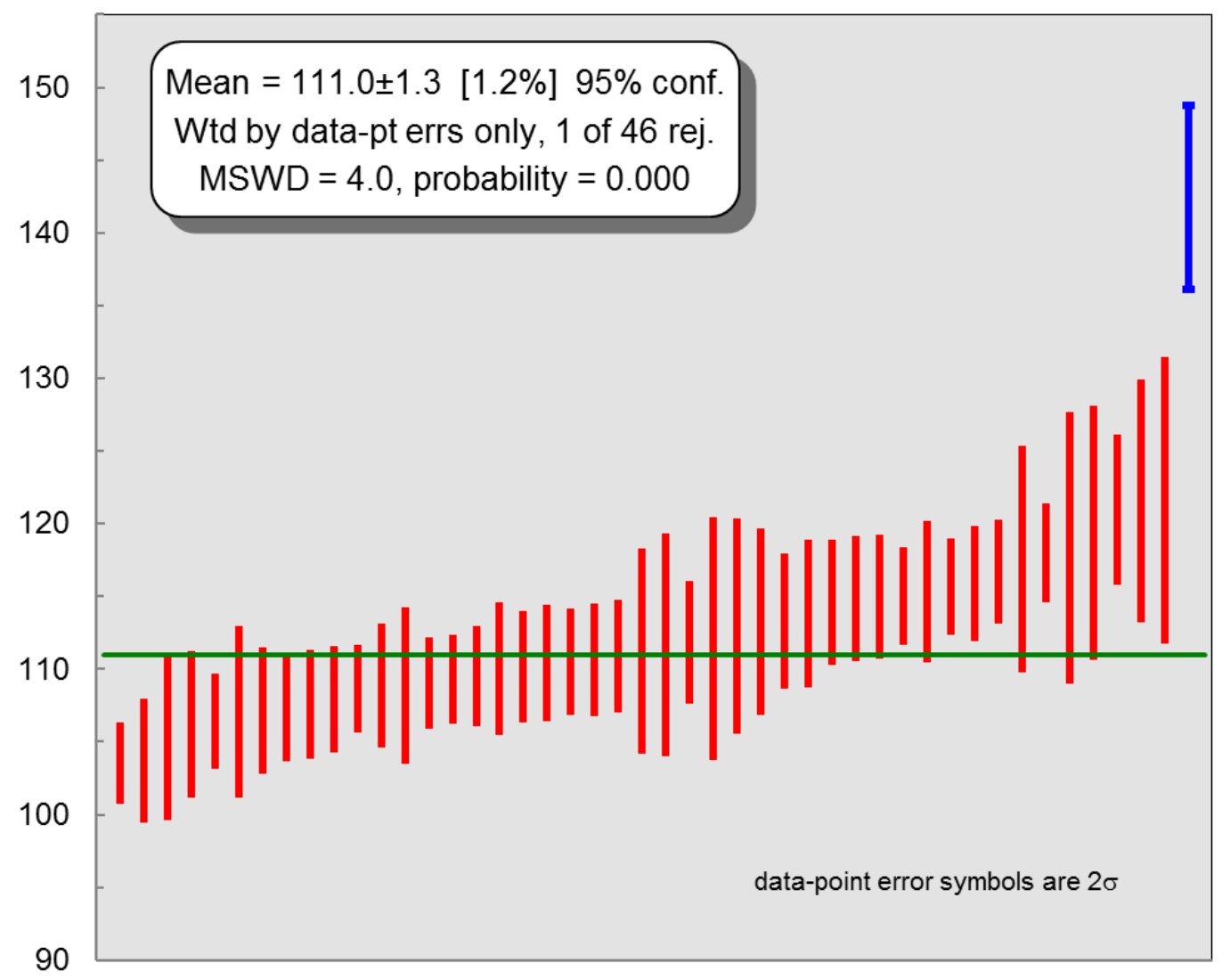

Figure 3e. Mean error-weighted ${ }^{206} \mathrm{~Pb} /{ }^{238} \mathrm{U}$ ages for 46 analyses, all with $<10$ percent relative error. The outlier at 144 Ma was rejected as statistically (95 percent confidence) not part of the main population. 


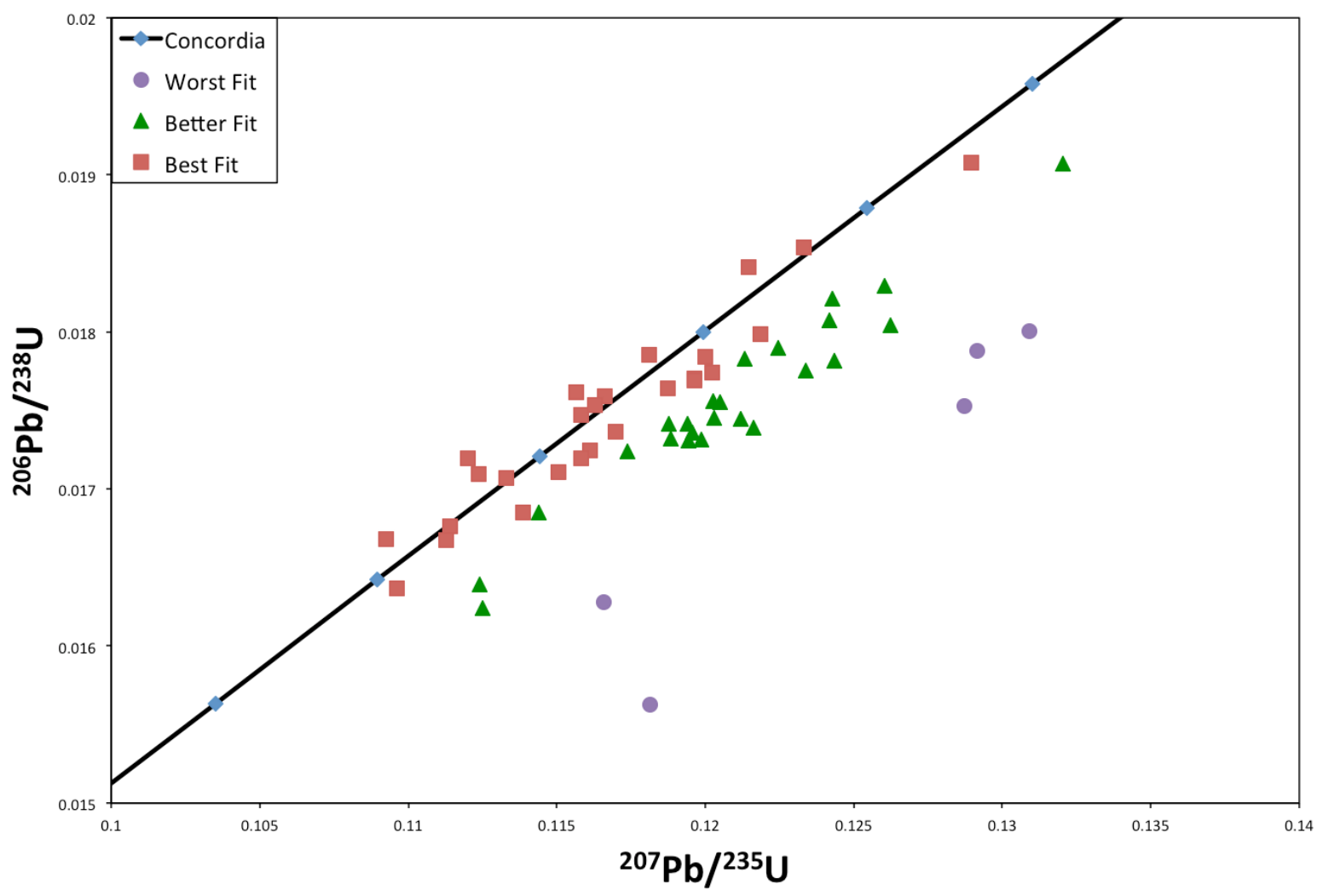

Figure 4 a. 55 sets of analyses with relative error $<10$ percent, plotted to express relation to concordia. 


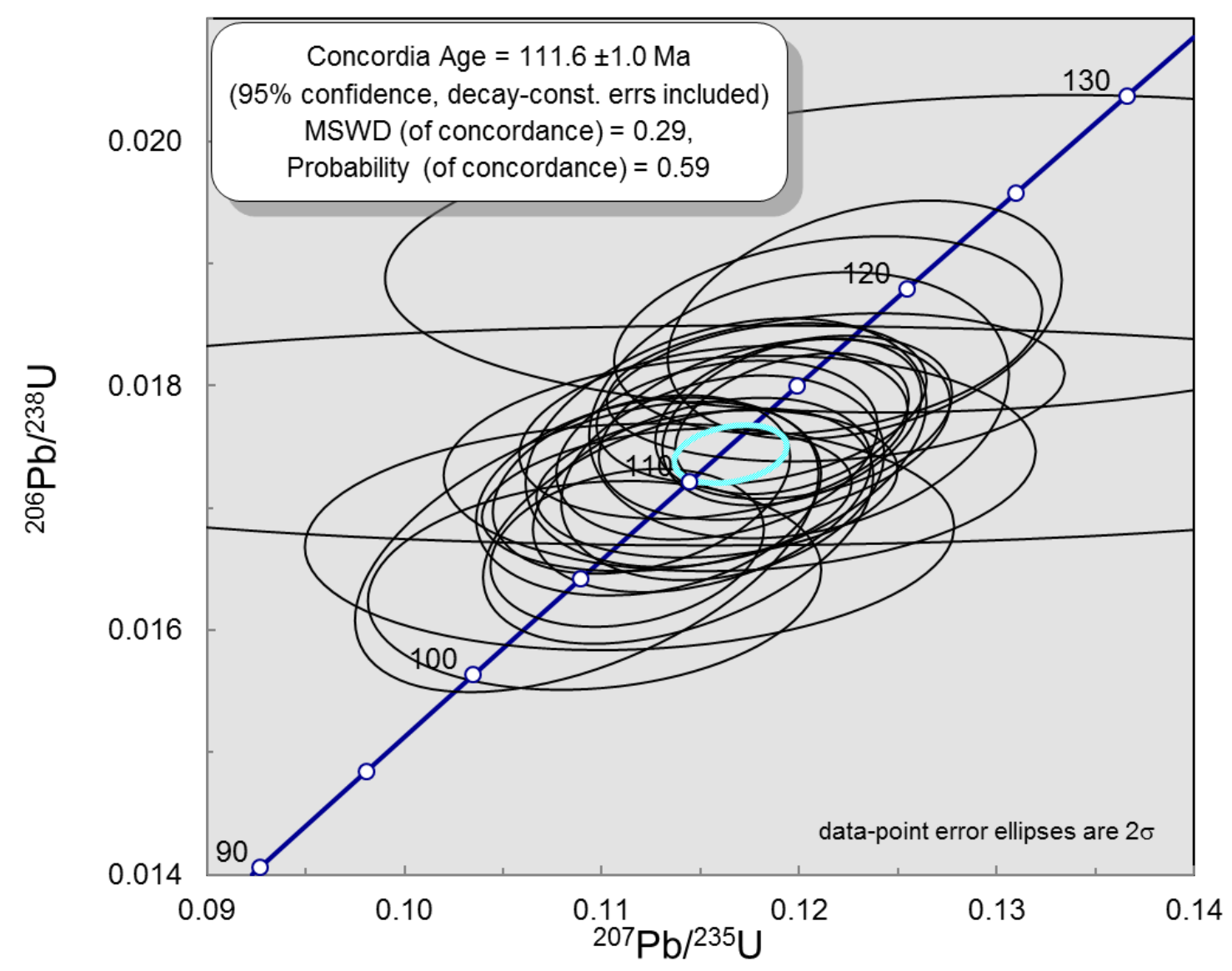

Figure $4 \mathrm{~b}$. U-Pb concordia-calculated age based upon 26 analyses, with ${ }^{207} \mathrm{~Pb} /{ }^{235} \mathrm{U}$ deviating from the concordia by $<2$ percent.

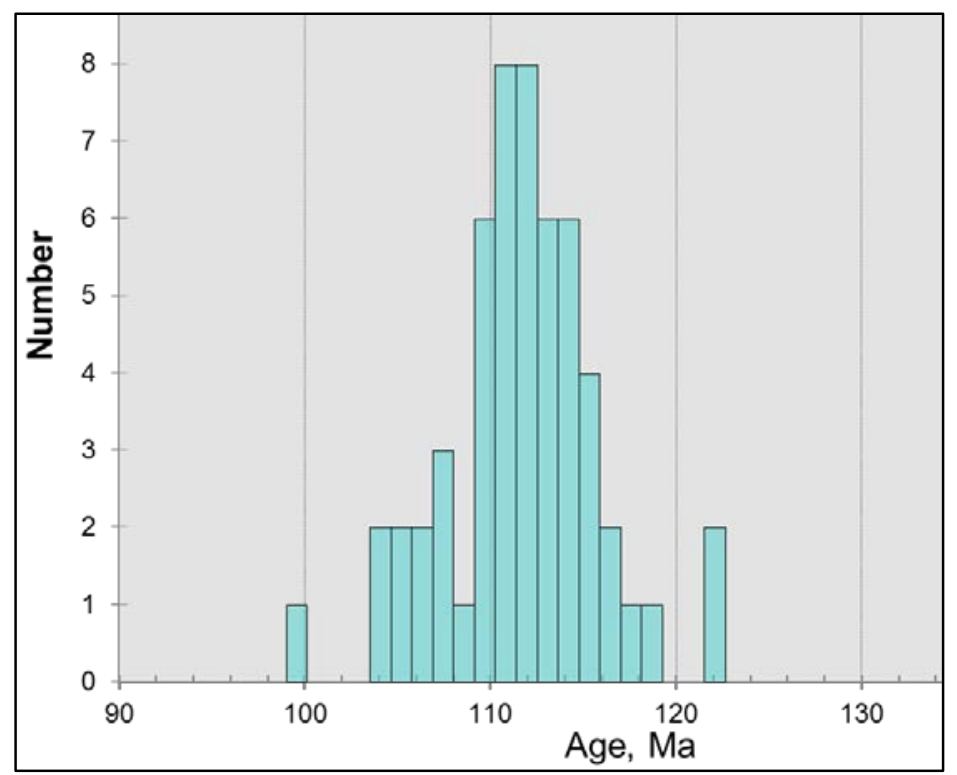

Figure 4c. 55 age measurements with relative error $<10$ percent. 


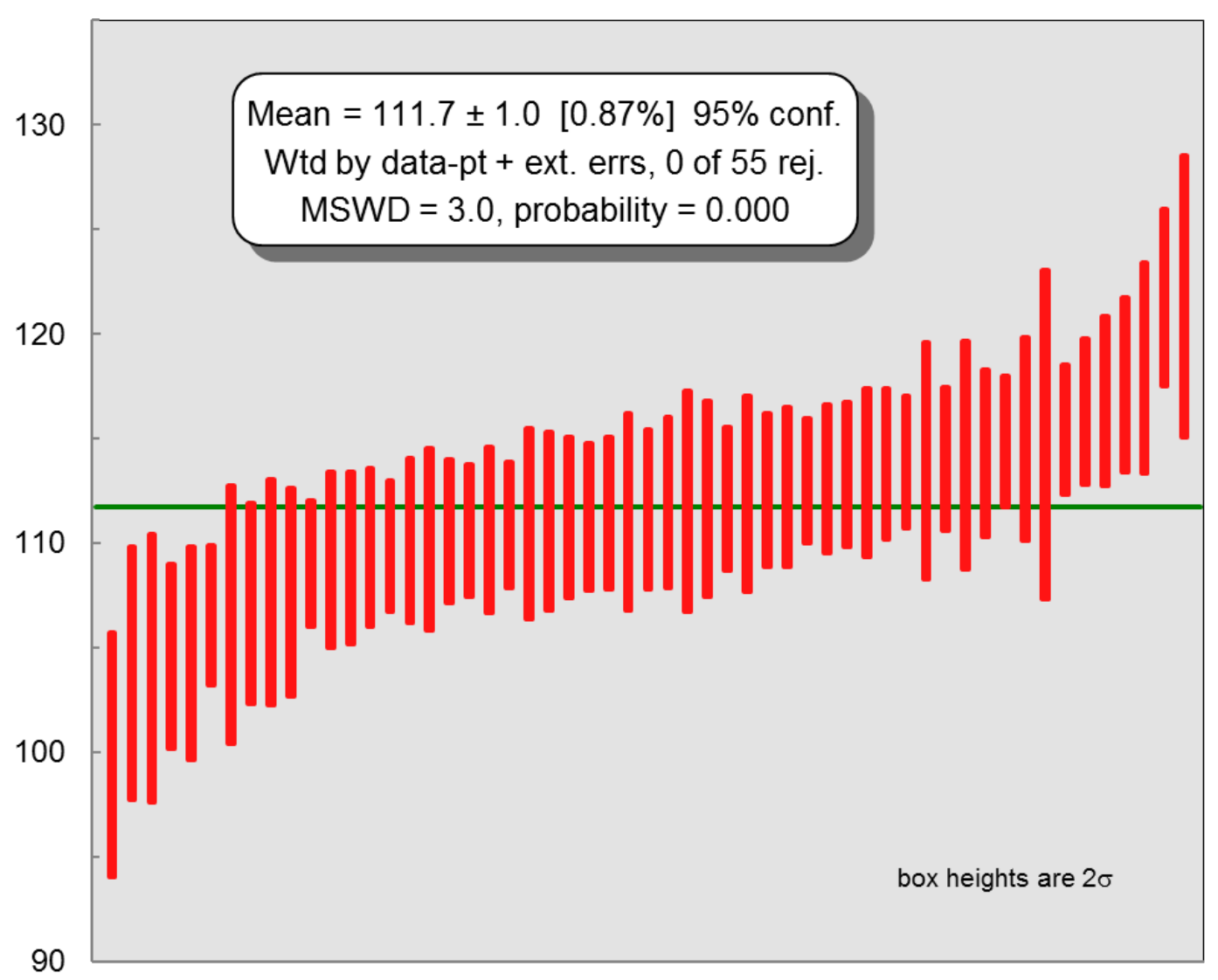

Figure $4 \mathrm{~d}$. Mean error-weighted ${ }^{206} \mathrm{~Pb} /{ }^{238} \mathrm{U}$ ages for 55 analyses, all with $<10$ percent relative error. 
APPENDIX B: ZIRCON AGE STANDARDS

\begin{tabular}{|c|c|c|c|}
\hline Standard & Standard & U-Pb Age $( \pm 2 \sigma)$ & Reference \\
\hline F5 & Duluth Complex & $\begin{array}{c}1,099.0 \pm 0.6 \mathrm{Ma} \\
\text { (assumed equal to FC- } 1 \text { ) }\end{array}$ & Paces and Miller, 1993 \\
\hline FC & Duluth Complex & $1,099.0 \pm 0.6 \mathrm{Ma}$ & Paces and Miller, 1993 \\
\hline IF & Fish Canyon Tuff & $28.201 \pm 0.012 \mathrm{Ma}$ & $\begin{array}{l}\text { Lanphere and Baadsraard, 2001; } \\
\text { Kuiper and others, } 2008\end{array}$ \\
\hline MD & Mount Dromedary & $99.12 \pm 0.14 \mathrm{Ma}$ & Renne and others, 1998 \\
\hline MT & Mud Tank Carbonatite & $732 \pm 5 \mathrm{Ma}$ & Black and Gulson, 1978 \\
\hline $\mathrm{T} 2$ & $\begin{array}{l}\text { Temora 2, Middledale Gabbroic } \\
\text { Diorite }\end{array}$ & $416.9 \pm 0.33 \mathrm{Ma}$ & Black and others, 2004 \\
\hline $\mathrm{T} 1$ & $\begin{array}{l}\text { Temora 1, Middledale Gabbroic } \\
\text { Diorite }\end{array}$ & $416.75 \pm 0.24 \mathrm{Ma}$ & Black and others, 2003 \\
\hline $\mathrm{TR}$ & Tardree Rhyolite & $61.23 \pm 0.11 \mathrm{Ma}$ & Dave Chew, personal communication \\
\hline
\end{tabular}

